УДК 341.4

\title{
LEGAL REGULATION OF UNIVERSAL JURISDICTION IN NATIONAL LEGISLATION: A COMPARATIVE ASPECT
}

\author{
ПРАВОВЕ РЕГУЛЮВАННЯ УНІВЕРСАЛЬНОӤ ЮРИСДИКЦЇ У \\ НАЦІОНАЛЬНОМУ ЗАКОНОДАВСТВІ: ПОРІВНЯЛЬНИЙ АСПЕКТ
}

\section{ПРАВОВОЕ РЕГУЛИРОВАНИЕ УНИВЕРСАЛЬНОЙ ЮРИСДИКЦИИ В НАЦИОНАЛЬНОМ ЗАКОНОДАТЕЛЬСТВЕ: СРАВНИТЕЛЬНЫЙ АСПЕКТ}

\author{
Присвячуеться 75 - річчю \\ Інституту міжнародних відносин \\ Київського національного університету \\ імені Тараса Шевченка
}

\section{A. Korynevych}

Philosophy Doctor in International Law, Associate Professor at the Department of International Law of the Institute of International Relations, Taras Shevchenko National University of Kyiv. E-mail: korynevych@gmail.com.

\section{O. Chubinidze}

Postgraduate student of the Department of International Law of the Institute of International Relations of Taras Shevchenko National University of Kyiv. Email: olexandra.chubinidze.fellow@gmail.com

\section{Кориневич А. О.}

Кандидат юридичних наук, доцент кафедри міжнародного права Інституту міжнародних відносин Київського національного університету імені Тараса Шевченка. E-mail: korynevych@gmail.com.

\section{Чубінідзе О. О.}

Аспірантка кафедри міжнародного права Інституту міжнародних відносин Київського національного університету імені Тараса Шевченка. E-mail: olexandra.chubinidze.fellow@ gmail.com

\section{Кориневич А. А.}

Кандидат юридических наук, доцент кафедры международного права Института международных отношений Киевского национального университета имени Тараса Шевченко. E-mail: korynevych@gmail.com

\section{Чубинидзе А. А.}

Аспирантка кафедры международного права Института международных отношений Киевского национального университета имени Тараса Шевченко. E-mail: olexandra.chubinidze.fellow@gmail.com

Abstract. The article reveals the peculiarities of application of universal jurisdiction in national law. In particular, attention was paid to the mechanisms for consolidating universal jurisdiction in the legislation of the Romano-Germanic and Anglo-Saxon legal systems, in particular as regards its subject-matter, personal and territorial application. An inalienable element of this study is the analysis of the powers and practice of the judicial authorities in this matter.

The main purpose of the article is a study of universal jurisdiction, based on classical cases of its consolidation in national law. Additionally, we provide the consideration of issues of practical 
application thereof in cases of war crimes. The conclusion is that national legislation has moved to a more narrow understanding of universal jurisdiction. Most often, in order to start a case, the complainant must be present before the national court. It is important that the offenses have a connection with public interests of the state iudex loci deprehensionis. The problem is also that the consolidation and application of universal jurisdiction at the national level has not been yet unified.

Key words: universal jurisdiction, national criminal law, comparative law, judicial authorities, grave crimes.

Анотація. У статті розкрито особливості застосування універсальної юрисдикиії у національному законодавстві. Зокрема, було приділено увагу механізмам імплементаціі універсальної юрисдикиї̈ у законодавстві романо-германської та англосаксонської правових систем, особливо, аспектам ї̈ предметного, персонального та територіального застосування. Невід'ємним елементом цього дослідження $\epsilon$ аналіз повноважень та практики судових органів з иього питання.

Основна мета статті - вивчення універсальної юрисдикиї, заснованої на класичних випадках ї̈ закріплення у національному законодавстві. Крім того, ми пропонуємо розглянути питання практичного застосування иієї конџепщії у кримінальних справах, особливо, предметом яких є покарання за здійснення воєнних злочинів. Загальний висновок статті полягає в тому, щуо національне законодавство перейшло до більш вузького розуміння загальної юрисдикиї. Найчастіше, для того, щэоб розпочати справу, суд вимгаає, щоб скаржник перебував на території держави суду. Важливою передумовою є також факт тісного зв'язку правопорушення із фундаментальними суспільними інтересами держави іиdex loci de prezurnienionis. Проблема також полягає в тому, щзо закріплення та застосування універсальної юрисдикиії на національному рівні є диверсифікованим навіть у рамках однієї правової системи.

Ключові слова: універсальна юрисдикція, національне кримінальне право, порівняльне право, судові органи, тяжкі злочини.

Аннотация. B статье раскрыты особенности применения универсальной юрисдикиии в национальном законодательстве. В частности, было уделено внимание механизмам имплементации универсальной юрисдикиии в законодательстве романо-германской $u$ англосаксонской правовых систем, особенно, аспектам её предметного, персонального $u$ территориального применения. Неотъемлемым элементом этого исследования является анализ полномочий и практики судебных органов по этому вопросу.

Основная иель статьи - изучение универсальной юрисдикиии, основанной на классических случаях её закрепления в национальном законодательстве. Кроме того, мы предлагаем рассмотреть вопросы практического применения зокрема в уголовных делах, особенно предметом которых является наказание за осуществление военных преступлений. Общий вывод статьи заключается в том, что национальное законодательство перешло к более узкому пониманию универсальнойюрисдикции. Чаще всего, для того, чтобы начать дело, суд требует, чтобь истец находился на территории государства суда. Важной предпосылкой является также факт тесной связи правонарушения с фундаментальными общественными интересами государства іиdеx loci de prezurnienionis. Проблема также заключается в том, что закрепление и применение универсальной юрисдикции на национальном уровне является диверсифицированным даже в рамках одной правовой системы.

Ключевые слова: универсальная юрисдикция, национальное уголовное право, сравнительное право, судебные органы, тяжкие преступления.

Formulation of the problem. Currently, international community is faced with bloody armed conflicts. During the operation in Syria thousands of civilians are becoming victims. Many other countries are suffering, because they are forced to divide their homes with the waves of migrants. 
Every day we see violation of human rights, which are the most important values enshrined in international law, and these violations constitue crimes against international law.

Ukraine is also experiencing a similar situation. During the aggravation of Ukrainian-Russian relations, the issue of responsibility of the parties to the conflict for their crimes is very relevant. In this context, accusations and convictions often occur at the level of national courts. They are the most effective instrument of condemning citizens of the other party for war crimes.

The purpose of the article. Our task is to figure out whether there is an effective mechanism to convict the perpetrators of the most serious crimes. There are mechanisms to punish the subject, whose actions affect the interests of all mankind. It is widely known and used both in international and national law, and called universal jurisdiction. The problem is that still, there aren't any unified principles for its application. In particular, the question arises, who can apply it and against whom.

Analysis of recent research and publications. A number of researchers can be referred to the authors who touched upon this issue. The criminal-law aspect of the jurisdiction of the states was considered in the works of S. Bassiuni, A. X. Butler, L. Benvenides, D. de Fabre, R. O'Keeffe, A. Cassese, M. Trave, L. Reidems, K. Rendal. Universal jurisdiction is a kind of criminal jurisdiction of states, so all the named researchers paid attention to it in their works.

Outline of the main research material. According to W. Shabas, the principle of universality is an exceptional, extraordinary basis for the exercise of criminal jurisdiction. It can be applied only to international crimes and only if the state, which under normal conditions (on traditional grounds) has to exercise jurisdiction over these crimes, do not wish or cannot do so [37, p. 156]. The universal principle is the application of national criminal law to foreigners who are in the territory of a given country and who have committed a crime outside the country that violates international law in accordance with international treaties. This criterion allows any state to establish jurisdiction over persons who have committed criminal acts abroad and does not directly violate the interests of that state or its citizens [43, p. 520].

Universal jurisdiction is an additional (subsidiary) type of jurisdiction that applies if another state that has a legal or factual connection with the crime (based on the territorial, personal, flag principle) cannot or do not intend to bring the perpetrators to justice. Therefore, the State of iudex loci deprehensionis must, before pursuing a judicial proceeding based on universal jurisdiction, make an appropriate request to the State where the crime was committed or to the State, whose suspected national it intends to prosecute the offender, except for the explicit refusal or undesirability of these states to prosecute [32, p. 467].

States have the right to grant their national courts universal jurisdiction over war crimes. The practice of States establishes this rule as the customary law of war crimes committed both in international and non-international conflicts. The same is true of other types of international crimes [26, p. 777]. To date, many countries have legislation that, under varying conditions, allows them to prosecute international crimes committed not by their subjects or in their territory. The successful prosecution of international crimes by the courts of Spain, France, Belgium and the United Kingdom at the beginning of the new millennium indicates that universal jurisdiction is now a practical reality that is gradually being assimilated into the functioning of criminal law systems in parts of Western Europe [34].

With regard to the range of crimes, the national law of many states contains very few grounds for the universalization of jurisdiction. In most cases, there is no specific listing of activities to which the extraterritorial jurisdiction applies. Formally, it can be argued that all crimes are subject to extraterritorial jurisdiction [44, p. 48].

However, on the whole, one cannot admit that States are not inclined to recognize one another's right to exercise jurisdiction in cases beyond the scope of international law. Obviously, this is why universal jurisdiction is most often recognized for only a limited number of crimes (including terrorism), as well as in cases, where there are reasonable fears that the offender may abscond in his or her own state and escape justice [44, p. 49].

The specific conditions necessary for a State to exercise universal jurisdiction over an international crime vary depending on the law of the particular State. Ultimately, these conditions 
are linked to two different concepts of this type of jurisdiction, which Antonio Cassese draws attention to [24, p. 284].

According to the narrow concept of universal jurisdiction, the presence of the accused in the territory of the state is a prerequisite for the commencement of the procedure for its implementation. According to the broad concept (or the concept of absolute universal jurisdiction), such a presence is not required to begin the procedure (although, of course, litigation cannot go in absentia, which would be a material violation of the suspect's rights) [24, p. 285]. The laws of each state, in one form or another, provide for the courts to exercise universal jurisdiction, ultimately either reflecting one of these trends, or relying on a mixed approach, assuming at least the "expected presence" of the suspect [31, p. 778].

"The practice is heterogeneous as to whether the principle of universal jurisdiction requires specific liaison with the prosecuting state. The requirement that the accused and the prosecuting State have any connection, in particular that the accused is in the territory or in the power of that State, reflected in the military statutes and regulations, legislation and case law of many states. However, there are also laws and case law that do not require such a link. The Geneva Conventions also do not require such a link, "- noted the authors of a fundamental study of the International Committee of the Red Cross on customary humanitarian law [31, p. 779].

For example, the laws of most countries that have criminalized international crimes in their domestic law require that the "actual" or "probable" presence of a suspect in the territory of a country must be prosecuted (forum deprehensionis). In some countries, the actual or expected presence of a suspect is a prerequisite for a preliminary investigation by the police [27].

It is especially important that allegations of prosecution of alleged criminals can be made by interested persons: victims, their relatives and representatives. There is a possibility of a judicial appeal against the refusal of the relevant authority to open an investigation.

One of the main trends in the application of universal jurisdiction is the establishment of elements of crime by the States [45, p. 9]. In the past century, national courts of individual countries have effectively applied the principle of universal jurisdiction as the legal basis for the prosecution and punishment of Nazi war criminals. Such practice was based on the recognition that the Nuremberg Justice was based on the principle of universality of the rules on the criminal liability of individuals for international crimes, which were considered to have unconditional priority over the rules of domestic law [7, p. 79].

Thus, in the "Hadamar" case, Alfon Klein and six other military men accused of violating the laws of war were brought before a military commission appointed by the US Seventh General. Considering the possibility of exercising jurisdiction, the commission noted:

"The commission had to decide whether it had jurisdiction, despite the fact that a crime committed by foreigners outside the United States did not affect the citizens of the United States. The Commission has resolved this issue in the affirmative [and thus] ... the grounds for the jurisdiction of the Commission derive from a recent general doctrine called "universality of jurisdiction in war crimes", endorsed by the United Nations War Crimes Commission, to which every independent state, under international law, has the competence to punish not only pirates but also war criminals who are under its authority, regardless of the victim's nationality or the place where the crime was committed, especially where for some reason the offender would otherwise go unpunished" [2, p. 51].

In addition, in the "Almelo" and "Zyklon B" cases, the same principle was used by the British military courts. The cases state that "under a general doctrine called the universality of jurisdiction over war crimes, each independent state has jurisdiction over international law to punish pirates and war criminals while in detention, regardless of the victim's nationality or place of residence, or place of committing the crime" [11, p. 41].

Subsequently, Nazi war criminal A. Eichmann (1962) was convicted in Israel on these grounds. The basis for the conviction was the Nazi and Nazi Collaborators Act, which was enacted in 1950. It lists the crimes to which it applies; asserts Israel's jurisdiction over Nazi suspects and repeals the prohibition on prosecution due to retroactivity and statute of limitations [20]. In 
appealing the case, the Israeli Supreme Court justified its jurisdiction by referring to the principle of universal jurisdiction in war crimes and crimes against humanity [16].

Eichmann's defender argued that Israel had no jurisdiction since Israel did not exist until 1948. The Genocide Convention also came into force only in 1951 and do not establish universal jurisdiction [1]. Israel claimed that it had universal jurisdiction on the basis of the "general nature of the crimes involved and that the crimes committed by Eichmann were not only a violation of Israeli law but also grave crimes against international law per se". It has also been argued that the crime of genocide is enshrined in customary international law [16]. The court ruled: "All the crimes charged by the appellant are not only international in nature, but also, given the damage and the deadly consequences, have been able to turn the whole international community upside down. Therefore, in accordance with the principle of universal jurisdiction, the State of Israel has the authority to judge Eichmann" [16].

The impetus for the use of instruments of universal jurisdiction by national courts gave rise to the establishment and functioning of the UN Special Tribunals, and then to the signing and ratification of the Rome Statute. Over the last decade, national courts of several states have already convicted a number of persons for international crimes, including those of non-international armed conflict, under universal jurisdiction. However, the states of citizenship of the accused did not object to the exercise of universal jurisdiction [31, p. 777].

Let us consider in more detail the provisions of national law, which set out the conditions for the application of universal jurisdiction, in particular absolute jurisdiction. We start with the countries of the Romano-German legal system as those, closer to Ukrainian law.

In view of the adaptation of the German criminal law to the provisions of the Rome Statute of the ICC, the so-called Code of Crimes against International Law, which was adopted and came into force in 2002, is of interest. The current German Criminal Code has been supplemented by a new first section, entitled the International Criminal Code (ICC). It provides for three types of international crimes, as enshrined in the norms of the Rome Statute of the ICC: genocide, crimes against humanity and war crimes, and defines the conditions for their prosecution. This is illustrated by the fact that the Rome Statute not only established the ICC, but also became a code of universal criminal law, qualifying the most serious international crimes and regulating in detail the necessary features of individual criminal responsibility under international law. The comments highlight different aspects of the prosecution of crimes committed outside and outside Germany. This means that no matter where the crime was committed, by whom or against whom, the perpetrators may be convicted on the basis of German criminal law. However, according to a new section - the ICC, the crimes committed therein are subject to universal jurisdiction [22].

The provision on universal jurisdiction is set out in Section 1: "This Law applies to all criminal offenses referred to therein against international law, to the offenses specified therein, even when the act was committed abroad and is not relevant to the territory of the country" [22].

These crimes are not subject to the statute of limitations (paragraph 5). The general principles of criminal law are applied in accordance with the German Criminal Code, unless otherwise provided (paragraph 2) [22]. An innovation for the criminal law of Germany is the provision on the responsibility of the higher command. It should be noted that command responsibility is a principle of martial law that imposes the responsibility of commanders for committing war crimes by subordinates [27]. Execution of command orders can justify the perpetrator of these crimes only in exceptional circumstances (p. 3) [14].

According to paragraph 1, genocide, crimes against humanity and war crimes are subject to universal jurisdiction, so German courts may hear cases of crimes committed by foreign nationals [22].

According to the principle of universal jurisdiction, the leader of the Rwandan rebels, the Democratic Forces of Rwanda's Liberation, Ignas Murvanashak was convicted and sentenced to 13 years in 2015. The trial of him and Straight Musson, also a Rwandan national, began in May 2011. This is the first case of using Code of Crimes against International Law in Germany. In September 2015, Strata was sentenced to 8 years in prison [39]. 
In 2017, an investigation was launched in Germany against Syrian high officials from the National Security Bureau, various intelligence and military police units on charges of committing crimes against humanity and war crimes. A similar investigation was launched against Syrian officers [38].

The article 689 of the French Code of Criminal Procedure refers to violations that fall under the jurisdiction of French courts and are committed outside the French territory by both French nationals and foreigners [7].

Universal jurisdiction gives France the power to determine and to impose penalties for specific crimes of common interest. In 2010, the French Code of Criminal Procedure was amended to extend the jurisdiction of French courts to all international crimes, as defined in the Rome Statute. However, the legislation has established four new conditions limiting the application of universal jurisdiction in French courts, which contributes to the formation of the so-called quasi universal jurisdiction [34].

The first restriction concerns torture and requires the suspect to be present in the territory of France at the time of the complaint; in the case of genocide, crimes against humanity and war crimes, the suspect must reside in France. In addition, there is no requirement of subsidiarity (giving priority to the courts of the country in which the crime took place or international criminal courts) or the principle of double criminality (when there is jurisdiction, even if the act was not recognized as a crime at the time of its commission), although both apply to other crimes of the Rome Statute. The fourth condition, which does not apply here, relates to the civil process [7].

The first case under the principle of universal jurisdiction began in 2009 on Rwandan genocide and crimes against humanity. Pascal Simbikangwa was the head of the Rwanda Central Intelligence Agency during the 1994 genocide. In 2005 he moved to Mayotte (a French island off the coast of Southeast Africa) [35].

The International Commission of Inquiry for Rwanda reported that Symbikangwa was involved in the Rwandan genocide - presumably as one of the main actors - and was eventually wanted by Interpol. On March 3, 2008, he was indicted in Rwanda for genocide and complicity in genocide, conspiracy and organized crime. On October 28, 2008, he was arrested in Mayotte for producing and selling counterfeit identity cards [35].

On February 4, 2014, the case of Pascal Symbikangwa was heard by the court of Dis Assis de Paris, and this was the first case in a French court of Rwandan genocide. In March 2014, a Paris court sentenced Simbikangwa to 25 years in prison. Confirmation of his sentence marks the completion of France's first successful prosecution of genocide in Rwanda [10].

In July 2016, a French court found Octaun Ngenzi and Tito Barair, two former mayors of Rwandan cities, guilty of genocide and crimes against humanity, and sentenced them to life imprisonment [35].

The experience of universal jurisdiction in Spain is interesting and instructive. Article 24 (1) of the Spanish Constitution guarantees: "Everyone has the right to an effective defense of a judge and a court in the exercise of his legitimate rights and interests and shall in no case be refused such protection" [6]. Until 2009, Article 23.4 of the Judiciary Act established that crimes such as genocide, terrorism, piracy "and any other acts which, according to international treaties and conventions, are to be prosecuted in Spain" are prosecuted by Spanish courts, even if they are committed by foreigners outside the territory of Spain [19].

Article 607 of the Spanish Criminal Code of 1995 establishes responsibility for genocide. Articles 608-616 establish responsibility for war crimes, regardless of whether they were committed in the context of an international or internal armed conflict (Art. 608) [12].

Article 125 of the Spanish Constitution [16], the Law on the Judiciary and the Code of Criminal Procedure provide for the right of Spanish nationals who have their own interests in a particular case or represent the victim to initiate prosecution in the form of private prosecution (accion popular) [18], [19].

The criminal prosecution in Spain, based on universal jurisdiction, started the case of Augusto Pinochet when a Spanish court requested the arrest and extradition of a former Chilean 
dictator in the UK. He was arrested in 1998 while undergoing treatment in the UK on a Spanish court order. Pinochet was charged with murder, Madrid demanded extradition, but failed to extradite: the court, and then the House of Lords, admitted that the former dictator as a head of state had immunity from prosecution. As a result, after two years of arrest, Pinochet returned to his homeland, where local law enforcement had charged him with the murder of political opponents, corruption, kidnapping and torture, as well as drug trafficking and the distribution of weapons [40].

Although Pinochet as a result has not yet issued, the case was a starting point for the continued use of universal jurisdiction in Spain. The following were the case against former Peruvian President Alberto Fujimori, the case of Argentinian officer Adolfo Shillingo, who was sentenced in 2005 by the National Judicial Chamber to 640 years in prison for crimes committed in the 1970s during Argentina's military dictatorship. [25, p. 78].

All cases currently pending before the Spanish courts in the universal jurisdiction have been brought in connection with statements made by victims or non-governmental organizations. That is, the decisive role was played by the accion popular procedure. In practice, until 2005, to establish jurisdiction of the Spanish court over international crimes committed by foreign nationals (which, under Spain's criminal procedure law, is set up by an investigating judge), the courts established a link between Spain's crime and interests. For example, in the Schillingo case, the reason for exercising jurisdiction was the fact that, among the hundreds of victims of crimes committed in an illegal place of detention, which included defendants, 14 persons were Spanish nationals [25, p. 80]. The situation changed in 2005, when, following the interpretation of the Spanish Constitutional Court, the existence of such a link was found not necessary to recognize Spain's jurisdiction over international crimes.

This unprecedented ruling was made in the context of the Spanish criminal case relating to crimes committed in the 1980s during the Guatemalan civil war (genocide case). It was launched in 1999 when his victims filed a complaint with the National Judicial Chamber of Spain in connection with the Mayan genocide in Guatemala. On March 27, 2000, an investigating judge declared that Spain had jurisdiction over the crime and commenced an investigation, despite the fact that no Spanish nationals were among the victims of the crime. However, the Supreme Court reversed that decision, citing the lack of a link between Spain's national interests and possible crimes [17].

This decision was challenged by the applicants before the Constitutional Court on the grounds of violation of their right to effective judicial protection. The Constitutional Court agreed with the applicants' main arguments and held that the Supreme Court had erred in its decision of 25 February 2003 and quashed it [13]. This gave impetus to new trials in accordance with the principle of universal jurisdiction. For example, on June 5, 2006, the Spanish Supreme Court recognized the right to hear a case of genocide to which the Tibet's population were subjected by Chinese authorities. An application for genocide against Chinese authorities was filed by expatriate Tibetan human rights organizations in Spain on June 28, 2005 [23, p. 597].

Thus, Spanish legislation on universal jurisdiction had an extremely broad potential by 2009. However, this has led to a sharp deterioration in international relations between Spain and a number of states, especially the People's Republic of China. Therefore, in 2009, the Spanish Parliament adopted amendments to Article 23.4 of the Judiciary Act, which narrow the scope of the principle of universality. It is now required that either the victim or the suspect be Spanish nationals, or that the suspect must be in Spain, or that the crime has to do with the interests of Spain. However, these amendments may conflict with Article 24 (1) of the Constitution of Spain in the interpretation given by the Constitutional Court of Spain $[6 ; 18]$.

In addition to Spain, Belgium has most actively used the principle of universal jurisdiction. In 1993, the Belgian Parliament passed the "Universal Jurisdiction Act", whose substantive jurisdiction extended to war crimes, crimes against humanity and genocide [30, p. 247]. In 2001, a group of Palestinians sued former Israeli Prime Minister Ariel Sharon and General Amos Jaron in Belgian court on charges of massacre of refugees at Sabr and Shatila camps in 1982 in West Beirut. The court against Sharon refused to start the case, citing the immunity of the head of state, and Jaron became accused, after which Israel recalled its ambassador from Belgium [21]. 
The turning point was the attempt by several Iraqi citizens to prosecute former US President George W. Bush, Vice President Dick Cheney and Secretary of State Colin Powell on charges of crimes against the Persian Gulf in Belgian court. The case began in March 2003. Washington then threatened Brussels with the loss of NATO capital status and the deterioration of relations, and as a result, the government, on the initiative of the government, restricted the right of the courts to institute cases against foreign statesmen [42]. Following this case, Belgium laid down the conditions for the application of the universal jurisdiction under which the accused must be a Belgian national or be in the territory of Belgium. As already mentioned, an arrest warrant issued in 2000 under this law against the then Minister for Foreign Affairs of the Democratic Republic of the Congo was challenged in the United Nations International Court of Justice in the Arrest Warrant case [4].

Also, in 2001, four Rwandan citizens were convicted and sentenced to between 12 and 20 years in prison for participating in the 1994 Rwandan genocide [41].

On August 1, 2003, the Belgian Parliament repealed the law on universal jurisdiction and approved a new law on extraterritorial jurisdiction, similar to the laws adopted in most European countries. However, some of the cases that have already begun have been considered further. These include those related to the Rwandan genocide and complaints filed against former President Chad Gissen Gabre (called "African Pinochet"). In September 2005, a Belgian court issued an international arrest warrant for Giessen Gabre on charges of "grave violations of international human rights". However, Senegal has never released Gissen Gabre. In February 2009, Belgium sued Senegal for refusing to extradite the former Chadian president. On July 20, 2012, the United Nations International Court of Justice demanded that the Government of Senegal "without delay" must either try Gabra on charges of crimes against him or extradite him to Chad. On June 30, 2013, Gissen Gabre was arrested in Senegal. On 30 May 2016, Gissen Gabre was sentenced to life imprisonment for crimes against humanity [28].

Let us now turn to the countries of the Anglo-Saxon legal system. Although the United States does not have a written law regarding universal jurisdiction, in some cases the federal government still detained suspected conspirators to commit U.S. crimes abroad or to commit crimes against U.S. officials. [36, p. 905].

In 1985, Humberto Alvarez-Mahaine, a Mexican citizen, was charged by the United States of America with torturing and killing in Mexico the agent of the United States Drug Enforcement Administration. Despite the existence of a bilateral extradition treaty, the US government hired a private individual, Mr. Sosa, to abduct Alvarez-Mahain from Mexico and return him to the US for trial. Alvarez claimed that his "arrest" by Mr. Sosa was arbitrary because the warrant only allowed arrests within the United States. The trial court found that Alvarez's arrest was unlawful. The United States Supreme Court in the United States v. Alvarez-Mahain case ruled that the US government had the right to "abduct" to bring him back to the United States for trial, because "the one-time case of Alvarez's unlawful detention is less than a day, followed by prompt bringing him to court does not constitute a violation of any international custom that would create a basis for appeal to a federal court" [9].

The Alien Tort Claims Act (ATCA), which is part of the United States Code, states: "Federal district courts should have jurisdiction over any foreigner civil lawsuit only if it relates to a breach of international law, or which results from a treaty, to which the United States is a party" [5]. Since 1980, courts have interpreted this law in such a way as to allow foreign nationals to sue U.S. courts for human rights abuses committed outside the United States [14, p. 394].

The main purpose of this law is to ensure accountability for violations of international law, in particular those concerning the rights of diplomatic agents and merchants [29, p. 239]. For example, the peace treaty that ended the American Revolution provided for repayment of debts to British creditors. The refusal of some states to repay such debts prompted Great Britain to blackmail - in 1784 an attack on a French diplomat was made, but he had no right to go to court. The incident received international publicity and prompted Congress to draft a resolution that recommended that states allow lawsuits to violate international law. However, only a few states have approved such a 
provision, and Congress subsequently incorporated the ATCA into the Judiciary Act of 1789 [32, p. $6]$.

In 1980, the Second Circuit Court of Appeal ruled in the Filartiga v. Peña-Iral case, which paved the way for a new conceptualization of the ATCA [32, p. 11]. Two Paraguayan citizens residing in the United States filed a lawsuit against the former Paraguayan police chief, who also resided in the United States, through the Center for Constitutional Rights. The plaintiffs alleged that the defendant had tortured and killed a family member and that the US federal courts had jurisdiction over this claim under the ATCA. The District Court dismissed the claim for lack of jurisdiction, holding that international law did not regulate the conduct of public authorities with their citizens [8].

The Second Circuit Court of Appeals overturned the district court's decision. First, he acknowledged that the ATSA was delegating the constitutional authority of Congress to the courts, since "international law ... has always been part of the common federal law", and thus the law falls under the jurisdiction of a federal court [8]. Secondly, the court stated that international law prohibits torture by public authorities. The Court found that the prohibition of torture in international and national law testifies to the consistent legislative practice of prohibiting torture. The Court also acknowledged that many United Nations declarations contain provisions for the prohibition of torture by public authorities. Thus, the right to freedom from torture has become a principle of customary international law [38, p. 395].

Presently, the use of jurisdiction by the United States over actions that have taken place overseas is a rather controversial issue. Multilateral settlement of these issues may be more acceptable, for example through the Organization for Economic Co-operation and Development or the UN.

With regard to the scope of ATCA's violations of international law, the Supreme Court in the case of Sosa v. Alvarez-Machin recognized that ATCA defended international rules that were specific, universal and binding. Torture, cruel, inhuman or degrading treatment, genocide, war crimes, crimes against humanity, prolonged arbitrary detention and forced disappearance - all of these crimes are subject to ATCA [36, p. 1198].

In the administration of justice under universal jurisdiction over persons committing international crimes, priority should be given to national courts. This provision is confirmed by the Rome Statute, which stipulates that the International Criminal Court complements national criminal justice systems (Articles 1, 17) [3, p. 3].

Conclusions. Having analyzed the practices of some of the states that have most commonly used universal jurisdiction, we can say that national law has moved to a more narrow understanding of universal jurisdiction. Most often, in order to bring a case, the complainant must be in the territory of the state court. It is desirable that the crimes have a connection with state interests. However, in the case of grave crimes under international law, such a link may not be taken into account. The relevance of the public interest is determined by the courts. In any case, states are trying to limit the widespread use of universal jurisdiction, which raises many problems: possible accusations of interference with the internal affairs of the state, a large number of complaints in the courts of more developed states from states where the judiciary is considered opaque, and so on.

The problem is that the consolidation and application of universal jurisdiction at national level is not uniform. There are no principles that would unify the grounds for its application and the entities responsible for it. It will be easier for countries in the Anglo-Saxon legal system to adopt such practices using judicial precedents. States of the Romano-German legal system, including Ukraine, should make major changes to their own legislation.

In general, the analysis and comparison of national legal principles of the application of universal jurisdiction, together with the practical aspects of its implementation, is the basis for identifying best practices with a view to its further successful implementation into Ukrainian law. 


\section{References}

1. Convention on the Prevention and Punishment of the Crime of Genocide, The Office of the High Commissioner for Human Rights. [Електроний pecypc]. - Режим доступу: 〈https://www.ohchr.org/en/professionalinterest/pages/crimeofgenocide.aspx>

2. Law Reports of Trials of War Criminals (L.R.T.W.C), Vol. 15. - [Електроний ресурс]. Режим доступу: <https://www.loc.gov/rr/frd/Military_Law/pdf/Law—Reports_Vol-15.pdf>

3. The Rome Statute of the International Criminal Court. (1998), The International Criminal Court (ICC). - [Електроний pecypc]. - Режим доступу: <https://www.icccpi.int/nr/rdonlyres/add16852-aee9-4757-abe7-9cdc7cf02886/283503/romestatuteng1.pdf>

4. Arrest Warrant of 11 April 2000 (Democratic Republic of the Congo v. Belgium). [Електроний pecypc]. - Режим доступу:

cij.org/docket/index.php?sum $=591 \& p 1=3 \& p 2=3 \&$ case $=121 \& p 3=5>$

5. 28 U.S. Code $\S 1350$ - Alien's action for tort. ). - [Електроний ресурс]. - Режим доступу: <https://www.law.cornell.edu/uscode/text/28/1350>

6. Constitución Española, Agencia Estatal Boletín Oficial del Estado. - [Електроний ресурс]. - Режим доступу: <https://www.boe.es/.../ConstitucionCASTELLANO.pdf>

7. Code de procédure pénale, Legifrance. - [Електроний ресурс]. - Режим доступу: https://www.legifrance.gouv.fr/affichCode.do;jsessionid=8D7A735D0F327A8D49651831AD2981 7E.tpdjo04v_2?idSectionTA=LEGISCTA000006151920\&cidTexte=LEGITEXT000006071154\&d ateTexte $=20090315>$

8. Case Filartiga v. Pena-Irala (577 F. Supp. 860): E.D.N.Y., 1984. - [Електроний ресурс]. Режим доступу: <https://law.justia.com/cases/federal/district—courts/FSupp/577/860/1496989/> 9. Case of Sosa v. Alvarez-Machain (03-339): 542 U.S. 692, 2004. 331 F.3d 604, reversed. - [Електроний ресурс]. - Режим доступу: <https://www.law.cornell.edu/supct/search/display.html?terms=sosa\&url=/supct/html/03 339.ZS.html.>

10. Case of the Public Prosecutor v. Pascal Simbikangwa. - [Електроний ресурс]. - Режим доступу: <http://www.internationalcrimesdatabase.org/Case/2241/Simbikangwa/

11. Case of Zyklon B. (Trial of Bruno Tesch and 2 ors, 1946): Law Reports of Trials of War Criminals (L.R.T.W.C), Vol. 1. - [Електроний ресурс]. - Режим доступу: <http://www.worldcourts.com/imt/eng/decisions/1946.03.08_United_Kingdom_v_Tesch.pdf >

12. Del Código Penal de Española, Noticias. - [Електроний ресурс]. - Режим доступу: <http://noticias.juridicas.com/base_datos/Penal/lo10-1995.html>

13. El Caso de Genocidio en Guatemala. - [Електроний pecypc]. - Режим доступу: $<$ http://cja.org/espanol—9/casos-3/el—caso-de-genocidio-en-guatemala/el—caso-degenocidio-en-guatemala-2/>

14. Gesetz zur Einfuhrung des Volkerstrafgesetzbuch: Bundesgesetz blatt (2000). Volume I.

15. Guatemala Genocide Case, CONSTITUTIONAL COURT OF SPAIN. - [Електроний ресурс]. - Режим доступу: <http://www.tribunalconstitucional.es/en/memorias/Documents/Memoria\%202005.pdf

16. Judgement District Court of Jerusalem, Case of Attorney General of Israel v. Eichmann (40/61), $1961 . \quad$ - [Електроний ресурс]. - Режим доступу: <http://www.nizkor.org/hweb/people/e/eichmann—adolf/transcripts/>

17. La Sección Tercera de la Sala de lo Penal de la Audiencia Nacional. - [Електроний ресурс]. - Режим доступу: <http://www.derechos.org/nizkor/espana/juicioral/doc/sentencia.html>

18. Ley de Enjuiciamiento Criminal. - [Електроний ресурс]. - Режим доступу: <noticias.juridicas.com/base_datos/Penal/lecr.html>

19. Ley Orgánica 6/1985. - [Електроний ресурc]. - Режим доступу: <https://www.boe.es > Buscar>

20. Nazis and Nazi Collaborators - Punishment - Law - 5710 - 1950. - [Електроний pecypc]. - Режим доступу: <http://www.mfa.gov.il/mfa/mfa—archive/1950 1959/pages/nazis\%20and\%20nazi\%20collaborators\%20 - punishment_\%20law_\%20571.aspx 
21. Sharon and Yaron, HSA v SA (Ariel Sharon) and YA (Amos Yaron), Final appeal/Cassation (concerning questions of law, Court of Cassation, 2003.

22. Völkerstrafgesetzbuch ("Code of Crimes against International Law"). - [Електроний pecypc]. - Режим доступу: http://www.iuscomp.org/gla/statutes/VoeStGB.pdf

23. Bakker C. A. E. (2006) Universal Jurisdiction of Spanish Courts over Genocide in Tibet:

Can it Work? Journal of International Criminal Justice 4: 595-601.

24. Cassese A. (2003.) International Criminal Law. London: Oxford University Press.

25. Colangelo A. (2005) The Legal Limits of Universal Jurisdiction, Virginia Journal of International Law 47: 77-81.

26. David E. (2012) Principes de droit des conflits armés. Bruxelles: Bruylant.

27. Danner A., Martinez J. Guilty Associations: Joint Criminal Enterprise, Command Responsibility, and the Development of International Criminal Law, UC BERKELEY SCHOOL OF LAW. - [Електроний pecypc]. - Режим доступу: <https://www.law.berkeley.edu/students/curricularprograms/ils/workshop/fall04_Martinez.pdf>

28. Dewan, Angela; Swails, Brent (30 May 2016). Ex-Chad dictator sentenced to life for war crimes. CNN. - [Електроний pecypc]. - Режим доступу: https://edition.cnn.com/2016/05/30/africa/habre-africa-chad-war-crimes/

29. Haberstroh, J. (2004) The Alien Tort Claims Act \& Doe v. Unocal: A Paquete Habana Approach to the Rescue in Denv. J. Int'l L. \& Pol'y: 231-241.

30. Halberstam, M. (2003) Belgium's Universal Jurisdiction Law: Vindication of International Justice or Pursuit of Politics? Cardozo Law Review 25.

31. Henckaerts J. - M. (2005). Customary international humanitarian law. Cambridge Univ. Press.

32. Hufbauer G., Mitrokostas N. (2004) International Implications of the Alien Tort Statute. St. Thomas L. Rev.

33. Lillich R. (1985) Invoking International Human Rights Law in Domestic Courts. U. Cin. L. Rev.

34. Mikhail A. Ahead of the Game: Prosecuting Syrian Crimes in French Courts, Lawfare, <https://www.lawfareblog.com/ahead-game-prosecuting - syrian-crimes - french - courts >

35. Trouille H. Universal Jurisdiction and Rwandan génocidaires: The Simbikangwa Trial [Електроний ресурс]. - Режим доступу: <https://academic.oup.com/jicj/articleabstract/14/1/195/2412001?redirectedFrom=fulltext>

36. Steiner H. (2008) International Human Rights in Context. London: Oxford University Press. 37. Schabas William. The UN international criminal tribunals: the former Yugoslavia, Rwanda and Sierra Leone. Cambridge University Press. 2006. 250 p.

38. Make way for Justice \#4. - [Електроний ресурс]. - Режим доступу: <https://trialinternational.org/wp — content/uploads/2018/03/UJAR - Make — way — for —Justice2018.pdf $>$

39. Rwanda: Ignace Murwanashyaka and Straton Musoni tried. - [Електроний ресурс]. Режим доступу: <https://www.bbc.com/news/world—africa-13275795.>

40. The arrest of Augusto Pinochet: ten years on. - [Електроний ресурс]. - Режим доступу: <https://www.opendemocracy.net/article/the - arrest - of - augusto-pinochet - ten - years —on >

41. Universal Jurisdiction in Europe. - [Електроний ресурс]. - Режим доступу: <http://www.hrw.org/en/node/11297/section/2>

42. War Crimes Suits Filed In Belgium Against Bush, Blair. - [Електроний ресурс]. - Режим доступу: <http://www.rense.com/general38/belg.htm>

43. Бойцов А. И. (2004). Выдача преступников [Extradition of criminals]. Санкт-Петербург : Юрид. центр Пресс.

44. Измайлова П. Р. (2015) Уголовная ответственность должностных лиц государства за преступления по международному праву : дисс. канд. юр. наук: 12.00.10 / [Criminal responsibility of state officials for crimes under international law]. Институт государства и права. Москва. 
45. Королев Г. А. (2010) Универсальная юрисдикция государств в отношении серьезных нарушений норм международного права :основания применения и порядок осуществления : автореф. дисс. ... канд. юр. наук: 12.00.10 / [Universal jurisdiction of states in respect of serious violations of international law]. Институт государства и права. Москва. 